\title{
WEURO 2017 as catalyst? The narratives of two female pioneers in the Dutch women's football media complex
}

\section{Rens Peeters, Agnes Elling \& Jacco Van Sterkenburg}

To cite this article: Rens Peeters, Agnes Elling \& Jacco Van Sterkenburg (2019) WEURO 2017 as catalyst? The narratives of two female pioneers in the Dutch women's football media complex, Soccer \& Society, 20:7-8, 1095-1107, DOI: 10.1080/14660970.2019.1680506

To link to this article: https://doi.org/10.1080/14660970.2019.1680506

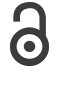

(C) 2019 The Author(s). Published by Informa

UK Limited, trading as Taylor \& Francis Group.

曲 Published online: 21 Oct 2019.

Submit your article to this journal $\widetilde{ }$

山 Article views: 136

Q View related articles $₫$

View Crossmark data \lceil 


\title{
WEURO 2017 as catalyst? The narratives of two female pioneers in the Dutch women's football media complex
}

\author{
Rens Peeters ${ }^{a}$, Agnes Elling ${ }^{b}$ and Jacco Van Sterkenburg ${ }^{a}$ \\ aErasmus University Rotterdam, Rotterdam, The Netherlands; ${ }^{\mathrm{b}}$ Mulier Institute, The Netherlands
}

\begin{abstract}
2017 was a significant year for women's football in the Netherlands. The Dutch women's team won the Women's European Champions football (WEURO 2017) for the first time in history. The screenings of their matches attracted massive audiences. This article explores the meanings given to gender and sport and the impact of WEURO 2017 by turning to two women pioneers in the field of elite women's football and the sports media complex. We not only study how these women negotiate and experience the impact and meanings given to WEURO 2017 but we also explore how their narrativesprovide insights in the wider meanings given to (the development of) women's football in the Netherlands. Results show, amongst other things, how an increased popularity and attention for women's football from the part of the media goes together with a reproduction of hegemonic discourses that prioritize emphasized femininity and construct men's football as normative.
\end{abstract}

\section{Introduction}

But above all, I wish that I can read about women's football in 'my' Parool ${ }^{1}$ And not only when we have become European Champion! (Merel Van Dongen, player of Ajax Amsterdam, 24 May 2017).

Thus ended an almost 700 words-long Facebook-post by a Dutch elite female football player on the 24 May 2017. The post which carried the title 'Het Parool, more for men?' was above all an impassioned plea for better media coverage of (national) women's football. More specifically, she directly responded to what she perceived to be a lack of proper coverage by Het Parool - a 77-word newsflash propped up in the corner of a page in the sport section was all she found - of her team winning the elite national football competition, the women's Eredivisie. She was especially perturbed as the newspaper and the club were both based in Amsterdam. Furthermore, the post proved to be prophetic in a double sense as the Dutch national women's team managed to become European Champion in their own country barely three months later. We consider this Facebookpost as a useful starting point to further investigate the complexities surrounding the struggle for recognition of women's football in the Dutch sports media landscape and the meaning and impact of the historic win of the Dutch women's football team of the European Championships 2017 (WEURO 2017) in this regard.

A focus on the development of women's football in the Dutch context is of particular interest as the success at the Women's EURO 2017 came at a moment in time when the sport already found itself in a stage of stimulation and popularization ${ }^{2}$. The year 2007 marked the initiation of the semiprofessional national competition, the Women's Eredivisie, that went through various revisions and 
was for three years (2012-2015) a transnational Belgian-Dutch cooperation. The Dutch national team did not qualify for an international tournament before EURO 2009, where they successfully reached the semi-finals. The following appearances in 2013 (EURO) and 2015 (World Cup) saw early eliminations for the Dutch, but nonetheless showed a gradual increase in television reporting and audience building. Being the host nation for the EURO 2017 and eventually winning the tournament were important ingredients for 'winning' even more citizens to view and support the 'Orange Lionesses' (Oranje Leeuwinnen). Around 10.2 million Dutch viewers (out of total of 17 million) managed to catch something of the matches from the national team and the final itself was viewed by almost 5.5 million people. ${ }^{3}$ All matches of the Dutch team were sold out and the honouring of the team in Utrecht was viewed on TV by 2.1 million people (Algemeen Dagblad online, 8 August 2017). The feeling that this was a turning point for the sport was furthered in several mainstream media, with statements like 'the entirety of the Netherlands is convinced' (De Telegraaf online, 3 August 2017). In one article, a marketing professional was quoted: 'These girls will go down in history as the accelerator of women's football in the Netherlands' (NRC online, 4 August 2017).

Mega events such as the Olympics and international tournaments have been studied by feminist sport scholars to investigate both the quantity and quality of media coverage on women's sports. Through the utilization of critical feminist content or discourse analyses (and variants thereof), they uncovered a set of - slowly shifting - gender inequality discourses and patterns in media representations of women's sports in various geographical contexts and media systems. ${ }^{4}$ In our own research on the trajectory of media coverage of women's football in the Netherlands in the last two decades, we identified a dual development from marginalization to professionalization. ${ }^{5}$ First, from a period of almost non-existent coverage of the game in the years 1995-2007, the new national competition and more actively the participation in international tournaments produced an increase in coverage. Second, the coverage itself honed in on the game itself, mostly by the adoption of gender neutral language to report on matches. However, at the same time, ambiguity remained by journalists adopting a normative framework to explain the sport (contra men's football) and narratives addressing mainly a heterosexual male audience. This is illustrated by the comparison of performances of female footballers to those of male professional players and headlining articles explicitly promoting the (hetero) sexual image of the sport. However, analysing media representations of female athletes might obscure as much at it reveals. A deeper understanding of gendered media coverage, including social media, also requires insight in the production process and audience consumption and meaning making. ${ }^{6}$

To generate in-depth knowledge into the dynamic gendered mechanisms at play within women's football and the sports media complex, we focus on the gendered spaces and contexts around mediating women's football. ${ }^{7}$ We heed the advice of Bruce ${ }^{8}$ who argued to look for those individuals who are making a difference' in the changing sport media landscape. Therefore we turn to the stories of two women 'pioneers' in the field of elite women's football and the sports media complex. Through their narratives on developments in the field and their experienced impact of the Women's Euro 2017, we study the operation of hegemonic discourses within the mainstream sports media complex, the ways these discourses are negotiated by the women themselves, and alternative spaces of meaning making where change and transformation may occur.

\section{Theoretical framework}

Within the context of women's football, it's the struggle for recognition that has been an integral part of the sport and the lives of those who participate in it. ${ }^{9}$ The Facebook-post by the Ajax player Merel van Dongen that we started this article with is a prime example of this 'battle over symbolic power'. ${ }^{10} \mathrm{Van}$ Dongen's post reveals how a specific narrative can be mobilized to argue for a specific viewpoint - the argument for better media coverage of women's club football - by engaging an audience (both specific and imagined) in her narration. ${ }^{11}$ Narrative is a key ingredient in Couldry's theoretical notion of voice 
and it is this term that we employ to understand and analyse the stories of our two interviewees. ${ }^{12}$ For Couldry, voice is a concept that has two important components: voice as a process and voice as value

Voice functions as a process in that people give 'an account of one's life and its conditions' by telling a story/narrative. ${ }^{13}$ While we highlight the stories of two women in this article, voice is never just an individual praxis, but is necessarily produced in a larger context as it requires both socially determined resources (language) and the status one needs to be recognized as having a voice by others. ${ }^{14}$ This also implies the possibility for a voice to be misrecognized and or remain unheard. Voice thus also is a form of agency that has a reflexive component, as it's precisely the desire to exchange narratives between individuals and/or groups and the subsequent advancement beyond mere discourse to incite action in the world. The inherent sociality of voice does not mean that each individual voice does not have a specific and distinctive capacity. Indeed, it is not our goal to provide a general account for understanding how Dutch women experience working within the confines of the sport media complex, but the different and distinctive embodied positions from which our two subjects speak has to be taken into account. ${ }^{15}$ To understand and discuss voice as both an individual and social act in the context of women's football, it is key to acknowledge the way structural markers of inequality such as gender, race/ethnicity, sexuality and others play a crucial part in the (re)production, but also the recognition or misrecognition of certain voices. We thus situate these two life stories in the appropriate social, cultural and political context and seek to connect biography and society. ${ }^{16}$ To put it differently, we analyse how individual accounts 'speak through' and reflect societal discourses in a certain time and place and vice versa; how individual narratives help shape societal discourses.

Here, the second component of voice, namely voice as value, is coming into play. Couldry defines it as the act of 'valuing those frameworks for organizing human life and resources that themselves value voice (as a process). ${ }^{17}$ According to Couldry, the domination of neoliberalism in the areas of politics, the economy and culture has produced a crisis of voice as it works as a voice-denying rationality. The often celebrated notion of 'freedom' under neoliberalism may seem to promote voice (and it can in some cases contribute to it), but in the end this notion of freedom is inadequate as it presents an ideologically motivated notion which propagates markets as the privileged spaces for voice. It's what, Mirowski argues, is a recoded and heavily edited notion of freedom to fit it in the framework of neoliberal thought. ${ }^{18}$ A notion of freedom that's not a 'realization of any political, human or cultural' goal, but one that instead emphasizes the idea of autonomous and self-governing individuals who are rational, in the neoclassical tradition, and improve their being by engaging in market exchange. ${ }^{19}$ Such neoliberal shifts are also recognizable in 'new feminisms' where individuality, choice, agency and empowerment are emphasized, without recognition for persistent inequalities, like for example the surveillance, disciplining and sexualization of women's bodies. ${ }^{20}$ Examples of such neoliberal discourses have also been recognized and critiqued by feminist researchers in relation to the marketing and mediation of women's sport in general as early as the $1990 \mathrm{~s}^{21}$ (and more recently also in relation to the mediation of women's football). ${ }^{22}$ Most important for our study here is to try and understand 'how current discourses are being internalized, embodied, and practiced by (sports)women as they make meaning of, and respond to, the conditions of their lives. ${ }^{, 23}$

As the Women's Euro 2017 turned out to be a success, we are interested in how both our subjects perceived its role for themselves within the larger context of the development of women's football and changes within the sport media landscape. To what extent did they adopt, negotiate or criticize general popular narratives of the tournament as being a catalyst bringing about a definitive breakthrough for the sport and its status within the wider sport media landscape.

\section{Methodology}

We choose to highlight the sport and professional biographical narratives of two women who occupy a fairly unique, pioneering, position in the sports media complex with regards to women's football. Such personal accounts may certainly not reflect all women working within the sports 
media complex, but do give more than 'personal accounts' because they make use of more collective narratives among the specific - marginalized - groups (e.g. women's football players, female sport journalists) they identify with and more dominant discourses in society regarding women's football. ${ }^{24}$

We held two in-depth biographical interviews with each of the two respondents. The first interviews were conducted in April 2017 and the second interviews were held in October/ November 2017- some time after the Women's EURO 2017 final had taken place - and lasted between 75-115 minutes. The first interviews were largely open ended and thematic, letting both women narrate their history both on and off the pitch. In the second interviews a mix of open ended and more focussed questions was adopted, which led to the interviews becoming more conversationalist in style. During each interview, the women were informed of the purpose of the study and their rights as a participant in the research. Although they each voiced no objections to using their personal data, with the possibility of being identified since they occupy such a unique position, we pre-emptively choose to employ pseudonyms.

It's important to stress our own 'strategic location' as researchers, as Sykes ${ }^{25}$ notes, because although it's impossible to eliminate the textual appropriation of the interviewee, it can be counteracted to some degree by explicating our own positions and clarifying how we studied and analysed the respondents' narratives. ${ }^{26}$ The first author conducted all interviews and is a white, heterosexual male in his thirties, who worked as a $\mathrm{PhD}$ Candidate on the inequalities and intolerances in the (Dutch) sport media complex. Hailing from the same generation as the women and working a job of a relatively precarious nature connected him in some way to the lives of these women. However, although being familiar with the current state of women's football, as a man he is a complete outsider to the sport, concerning the experiences of girls and women playing and working in the male dominated world of football and sport media. Since an interview is a product created by the interaction between both the interviewer and the interviewee that takes place verbally as well as through non-verbal cues, being unfamiliar with their specific experiences may have prompted neglect of certain avenues for questioning and instead 'dig deeper' into other issues. ${ }^{27}$

The interviews were recorded and fully transcribed after which the transcript was reconstructed into a narrative, combining a chronological structure with a thematic approach. ${ }^{28}$ The narrative was discussed among the research team and sent back to the respective interviewees as part of a member check to promote ethical practice. ${ }^{29}$ In several meetings with the other two authors, main overt/ closeted themes were discussed. The second author is a white lesbian woman with an extensive working record on issues of social inequality in (women's) sports as a critical sport sociologist and a former career in competitive sports, but not football. The third author is a white, heterosexual male, working as a university researcher in critical sports (media) studies.

The interviewees were allowed to make comments on the narrative and ask for corrections/ deletions. After completion of the final narratives, in a dialogic process of creation three main narrative themes were identified. These themes illuminate some of the complexities that exist in the everyday struggle for recognition and giving voice on women's football that these women are enmeshed in. The themes we identified in the narratives were: 1) gender negotiations, 2) freedom and constraints, and 3) WEURO 2017 as catalyst. Before turning to the narratives of the two women, we now first sketch (briefly) their background.

Lisa and Emma (pseudonyms) both played football since their early childhood and made distinctive interventions into the sports media complex in their own particular ways. Both women are white, in their thirties and single, they grew up in the large cities of the western part of the Netherlands and were raised in middle-class families. As young girls they both started playing football at local clubs in the 1990s when participation in women's football was growing, but was still marginal. ${ }^{30}$ Where Emma always played in all-girls/women squads and on amateur basis, Lisa played in boys' teams until her teenage years and continued to play at the highest competitive level in women's football, followed by a professional career and a short career as international. Emma studied journalism and has been working as a freelance journalist for a national newspaper and 
sport magazines for around a decade. She specialized in women's football. In 2015, she successfully organized an online crowd funding campaign to be able to attend the FIFA Women's World Cup in Canada. Prior to WEURO 2017, she published a book with portraits and stories of players and other girls and women in and around the Dutch national women's football team.

Lisa obtained a master's degree in communication science during her elite football career. After having had to quit football at the elite level, partly as consequence of a heavy injury, she was given the opportunity to head a company that sells female football clothing and apparel. Furthermore, she started a YouTube programme that exclusively cover's women's football.

\section{Results}

In this section we present the results of our narrative analysis of the two separate stories we constructed from the interviews with our subjects. Their narratives show how Lisa and Emma, in their own ways, negotiated and intervened in the hegemonic discourses surrounding women's football and gender. The Results section is followed by a Discussion where we bring together and further reflect on both narratives.

\section{Lisa}

\section{Negotiating gender}

Similar to earlier other accounts of the life histories of elite women football players, ${ }^{31}$ Lisa was confronted with the framework of traditional gender roles in her childhood both in the formal setting of club football and the informal setting of after school football in the neighbourhood. Although she mostly felt at ease as 'one of the boys' in the boys' teams she played, entering puberty things changed, 'because suddenly, the fact that you're a girl gets underlined and that maybe, you don't belong in a team'. She was searching whether to continue with the sport at all, even though her talent was recognized and she was stimulated to continue. Which she did and later in her career mainly pushed herself to become an elite player.

Her personal experience as a football player is in some respects reflected in the rationale for developing a women's football brand after her football career. By providing young girls with the opportunity to play in 'fitting clothes' or 'girls' clothing', Lisa feels she is providing a prerequisite to feel welcome and at ease in the sport. 'I believe that what I show now with my brand is that you, all this time, you were required to walk around looking foolish. Yeah, what do you call it, that they weren't taken serious. You had to walk around in men's clothing.'

This works in tandem with what she sees as the image problem of women's football, which she locates in the opinions of the male audience: 'Girls playing in girls' clothing also creates the condition that the men who watch it take it seriously, because they're girls instead of them saying: 'there are those mannish women in those burlap sacks". It's not only the men in the audience, but also the men in the boardrooms and those 'men who watch over the money' that she has to contend with. Although it's sometimes a battle, she argues that the title win at EURO 2017 has made things easier as those men have made the transition from being 'a hindrance' to being 'totally overturned'.

Apart from negotiating with men, there's also the women players themselves who are not always convinced. Lisa describes a change in the sort of girls who nowadays make up most of the football teams, which echoes journalist positive accounts of and focus on today's '(hetero)sexy players' ${ }^{32}$ If you now see the youth teams, you see eleven ponytails. You do have a couple of tough girls walking around, but it's not like in the past. Yeah, where it was sometimes definitely difficult to see if it was a boy or a girl walking on the pitch ... Real girly-girls who play football. You almost don't see any difference anymore between a [field] hockey team and a football team.

Lisa encounters more scepticism with a subset of women who feel fine with playing in their current (male) outfits. According to her, every team 'has such a player or sometimes it's a group', mainly belonging to 'the older generation' that don't really like her clothes. She finds it difficult to 
convince these women that her brand doesn't consist of 'hot pants with a sort of elastic, super snug shirt'. It bothers Lisa somewhat that she can't appease every girl and woman as she currently doesn't have the financial capabilities to broaden her line with some sort of 'unisex kit', but she is mainly pleased to make most of the girls/women in a team happy.

\section{Freedom, constraints, and a positive disposition in an uncertain world}

Creating a female football brand wasn't the first thing Lisa thought of when she met hermale companion in 2015. After her master on communication, she voluntarily worked on a study on women's football and social media, with a main conclusion being a general lack of professional information and communication. So she aimed to intervene in this 'half-baked mess' and build some sort of platform to 'help the sport along', improving its brand image by providing 'those girls with a stage and really position them as heroes'. However, her initial ideas didn't get a follow up, mainly because lacking financial viability. Therefore, she and her companion decided 'to do something about the lack of female specific football clothing first' and envisioned to build a broader platform around the brand later on.

Working within the confines of a small start-up that travels in relatively uncharted territory allows Lisa some degree of flexibility and freedom in her approach, which switched from a more straightforward commercial approach to a more 'cheeky approach' to gain visibility, including outspoken critiques on the slow developments within women's football. She enjoys that she is able to try everything 'because the lacuna [left behind by the established media] is so big'. However, this freedom is obviously not unlimited, because as her company grows, she increasingly has professional relations with partners and clubs, where outspokenness is not always appreciated.

She feels that complaining about obstacles hindering the development of women's football always has to be complemented by 'bringing ideas to the table that put forward alternative ways of doing things'. This turns into a question of personal identity: '[...] because I want to be a [positive] person'. During the WEURO 2017, it was 'obviously super easy to be very positive', because the results of the national team kept reinforcing the positive vibe. She was asked to appear on television, radio shows or other media outlets during the tournament to fulfil the role of expert, and told the 'good story' she wanted to tell all along: 'In the end, I force myself to show that it's a sport with plenty of possibilities and that advances were certainly being made. And that was proven this whole summer'.Framed as a question of personal identity - being a positive person she also moves towards a more strategic, business oriented position, reserving her more critical voice for talks behind closed doors.

The relative freedom associated with her position in a start-up company comes at a certain cost as financial security remains an ideal rather than a reality. During her professional football career and the start of her business, she was financially supported by her parents ${ }^{33}$. She is sometimes 'pestered' by the fact that her finances aren't always in order, but hopes that invested time and energy will be repaid some day.In this regard, the EURO 2017 has provided her some financial buffer as she was able to land some paid gigs. Nonetheless, Lisa reminds that money was neverthe main objective for her and even would be 'a proud person 'should her initiatives remain profitless in the end,since she did all she could to boost the popularity of women's football .

\section{EURO 2017 - a new horizon?}

According to Lisa, women's football won't necessarily see a surge in the number of girls and women signing up at local clubs as a leverage of the tournament. Instead, she acknowledges improvement in the 'perception of the sport' and in the 'little things that're changing' in areas like the number and quality of facilities. Her view is that the sport is now regarded as a 'proper sport' and the WEURO victory as a 'top-class sport performance'. She recognizes 'maturation of the sport', by media that never paid attention to women's football before suddenly appearing 'up front with their camera's' 
and acknowledges that such can be rather 'frustrating for enthusiasts' who're suddenly overshadowed.

She didn't have such negative experiences herself, mainly seeing a positive end result for her company by promoting her brand by being asked as an expert for different kinds of media. Without doing a lot of acquisition in that period, clubs still found their way to their company. Her online YouTube show on women's football also rose in popularity during the tournament. ${ }^{34}$ She puts her own role in the larger sport media landscape in perspective: 'I'm just not that interesting. I'm just a small crumb, which doesn't lead to very unusual reactions'. The fact that some internationals are now famous players, is in Lisa's eyes not to say that this is the new normal for every Dutch female football player. The women's Eredivisie is still 'small and vulnerable' in her opinion and this won't necessarily improve because of the tournament victory. And although media attention will probably peak during tournaments or qualifying matches in accordance to other Olympic sports, she argues structural attention will be limited 'in comparison with men's football'.

\section{Emma}

\section{Negotiating gender and sexuality}

In her career as a football journalist, Emma mostly travels in spaces occupied by men. This has been the case since the start of her professional career as a writer for newspapers. Upon her entry at the national newspaper for which she still freelances, she was greeted by a team of only male (football) writers and editors. This wasn't a particular problem for her, instead she enjoyed the environment. Her approach to journalism is different than most other people on the staff as 'she sometimes forgets to ask the most important question', but then instead does 'know that someone has been married for six years or whatever'. It's an approach that's more attuned to the 'personal or sensitive' side of her subjects, which might make her 'a bit of a softie', but with this ability she's 'able to show the other side of football'. She's hesitant to call this style 'feminine', but does remark that overall, male writers more often tend to make 'a comparison between men's and women's football' in their reports and ask 'less [about] personal things' in their interviews.

However, some personal things such as the sexuality of female football players remains a 'thorny issue' for both journalists and players to this day. She notes that the stereotypical butch image of female football players has subsided throughout the years. But whether or not to report on the sexuality of players, when potentially relevant, for example regarding relationships between players from the same team or when partners play against each other, is something that 'nobody really knows exactly how to do this'. In her capacity as a journalist she won't highlight the topic in her work, because she 'wants it to be about the sport', similar to many lesbian football players: 'a lot of them are lesbians, but they just don't want that to be the story. They're just elite athletes.' Nonetheless, she remains conflicted herself about it, because in the end 'it shouldn't really matter' how these women present themselves to the world and what their sexual identity is. Although she 'can't fault men' who like the looks of some players - 'if I see a pretty male footballer on TV, I also nudge my girlfriends'-, she dislikes how some male journalists seem to prioritize such sexual preferences in their work. One journalist chooses to interview a certain player, because she looked 'so sexy' and he boasted about this against a male colleague, which, for Emma, is 'the worst form of journalism.'

\section{Freedom, constraints and the responsibility for women's football}

Emma refrained from writing about women's football in her early days as a newspaper journalist, because it would be 'too obvious' that she would take up that mantle as she was involved in the game as a player, a coach and as a fan. However, from 2012 onward, she decided to focus on the sport, amongst other things because she considered it interesting from a career and job security point of view, stimulated by her father and brother: 'if this [women's football] keeps growing steadily, which it looks like, then you've got your niche'. Her continued career as a freelance writer primarily of 
women's football - she still sometimes writes about men's football - is characterized by both a sense of responsibility towards the sport and financial limitations (comparable to many, especially women, journalists in current times). ${ }^{35}$

Money was problematic, for instance, when the national team managed to qualify for the FIFA Women's World Cup in Canada in 2015. The newspaper she worked for initially wasn't planning to finance her trip and stay, since they could get free articles from a fellow newspaper. Emma, however, managed to convince the editor-in-chief of her ambition and she was offered a one-way ticket in exchange for columns and match reports. She still had to cover the rest of the expenses and choose to follow up on the advice of her parents 'to go crowdfunding'. Once the campaign started, 'a boatload of money started pouring in' and she was 'pleasantly surprised' that people entertained a personal preference for her stories. She stayed in-house with a local family in Edmonton, instead of a hotel as most of her colleagues. She felt much responsibility towards her sponsors and wanted to make it 'very clear how the money was put to use'. Searching for direction at the start, she grew more confident and embraced her somewhat distinctive journalist position and thoroughly enjoyed working there.

Emma says she doesn't care much for not having money and she goes through periods where she has to rebuild her financial reserves by doing assignments and odd jobs, besides already doing a part-time job in the retail industry and her work as a football coach. The drive Emma has for writing about women's football is also represented in the connection she feels towards the players: 'But yeah, I do feel another connection than with the men. More, yeah, you level more. You know what they're going through'. She sees her own position reflected by the fact that these women 'are striving for a dream for which they don't get much in return, but which they enjoy doing.' When she started writing about women's football, she had to learn to balance her obligation as a journalist and the ancillary dogma of journalistic objectivity on the one hand with her sense of camaraderie with the players on the other.

It was not always easy for her to respond to actual critiques levelled at the sport, which she sometimes almost felt as personal insults. Behind the scenes at the sports desk of her newspaper she often enters into such discussions because it was sometimes fairly difficult to get her pieces on women's football published. She points towards 'a lack of empathy' on the part of most (male) sports editors, who often can't comprehend the importance of certain developments in women's football.

\section{Carving out a space as a journalist in the wake of EURO 2017}

Emma's book on female football players was released in spring 2017, just prior to WEURO 2017. It received attention from media outlets and sold 'in accordance with expectations'. The approaching tournament however saw the increase in media coverage and her book more or less 'dropped out of the media frame by all the articles that were written'. Not only that, the European Championship also brought with it the 'many unknown faces' in the world of women's football that populated the press briefings and the mixed zones, many of whom were 'sorely lacking in knowledge' about the game. In this setting, Emma, unwillingly, became a sort of beacon for many of those male journalists who asked her for example for pointers on who to interview. Her book was also popular among colleagues, but not every journalist acknowledged this in their work. Large media outlets with a broad social media presence would write and promote stories and interviews with players and brand them as unique, not acknowledging the fact that similar stories were already presented in Emma's book.

She was somewhat 'taken aback' by the media personalities that occupied many of the TV talk shows during WEURO 2017 and that found it 'fun to kick against' the sport, labelling it 'a hype'. It annoyed her that when a discussion was taking place on a prime time TV show about the tournament, it would more often than not veer into the territory of a 'men versus women' discussion. She herself was also once invited on such a show. Contrary to the early days in her career, this time Emma found herself stronger in her conviction to go against these voices: 'I kicked 
against this [narrative] wherever I could'. But it also left her with a sobering thought, that despite her expertise 'I just don't get heard ... you need friends or you need to have an important face'. This realization is also motivated by the new situation in the sport media complex that arose post WEURO 2017. Emma refers to the increased and sustained coverage of the game by major media outlets and an increased commodification of the players. According to Emma 'it's not strange anymore to report on women's football', but since it has become more routine coverage, many stories do not move beyond 'the descriptive' and journalists rarely go in-depth to figure certain things out. Where she was almost always guaranteed a one-on-one interview with a player, at the end of 2017 it's not uncommon to see three or four journalists sitting down with a big-name player for an interview at the same time.

Emma feels that during WEURO 2017 she 'got sucked into this competitive role' in which she didn't feel particularly comfortable. It has become more difficult to 'go her own way', and write her stories 'in the background'. It's impossible for her to patrol the borders of what once was her niche as now every other journalist 'has those contact details' of players and agents and has access to the sources on which she carefully build her stories. Compounded with the fact that she views herself as somewhat 'old-fashioned' as she is not always online and promoting her own brand on social media platforms, she found new employment after the tournament, but continues juggling jobs and obligations.

\section{Discussion}

In this article, we analysed how two young women narrate their experiences pioneering in the mediation of women's football within the Dutch sports media complex and the impact of WEURO 2017. Although we do not suggest that these two stories reflect the experiences of all women working in this field, analysis showed several common themes and discourses that both respondents and their colleagues have to negotiate. In Lisa's and Emma's stories on the ongoing developments regarding the mediation of women's elite football in the Netherlands and their own position within this dynamic field, several similar and different, experiences and voices can be distinguished. As Couldry suggests, these voices are the outcomes of negotiated processes, in which particular voices are clearly more recognized and privileged and others are rather misrecognized or silenced ${ }^{36}$. Furthermore, the particular articulated voices of Emma and Lisa not only reflect their authentic experiences, but also a certain, 'strategic situatedness' (e.g. pre and post WEURO 2017; young heterosexual male interviewer) of who they are, what they did and where they strive for. ${ }^{37}$

Their narratives clearly affirm the growing 'newsworthiness' of women's football over the last decade in the Dutch sports media, ${ }^{38}$ cumulating into sensational headlines and a summer's news fairy tale with the Dutch winning the WEURO 2017 tournament in their own country. ${ }^{39}$ To some degree both women view WEURO 2017 as a catalyst in the world of Dutch women's football, albeit one that occurred within a longer ongoing development of the game. However, these women were only able to reflect on the event and its immediate aftermath and they were careful in their assertions or simply unsure as to what it would amount to in the long run.

Apart from the international success being the main precondition for the increased and more 'professional' media coverage of women's football, former research showed how the rise in celebratory voices is accompanied by a growing commercialization and (hetero)sexualization, fitting the market economy logic 'sex sells'. ${ }^{40}$ In their narrative accounts, Emma and Lisa use a more neoliberal or 'third wave' feminist perspective, and regard such reclamations of signs of (heterosexy) femininity as empowering rather than disempowering. ${ }^{41}$ Both Emma and Lisa refer to the different appearance of current elite women and amateur girls players ('eleven pony tails', 'girlie-girls') that subsided the butch, mannish image of Dutch women's football in the past. ${ }^{42}$ Their negotiated voices regarding the representation of gender and sexuality also partly differ, reflecting different experiences and (strategic) positions. Especially Lisa's narrative echoes an interpretation of this shift in the (self)representation of women football players towards a heterosexy feminine body- 
image as positive, signifying power and achievement instead of sexual objectivation. For Lisa, this also seems a kind of personal victory over a negative image that burdened her and the development of women's football in the past. With her women's football clothing brand she now actively and strategically supports this new, positive public image of women's football. Furthermore, Lisa also seems to regard this 'changed image' as one of the major accomplishments and sustainable social impacts of the WEURO 2017. ${ }^{43}$ However, this celebration of the 'feminine football player' partly coincides with a silencing of lesbianism and devaluation of butchness. ${ }^{44}$ Lisa's voice is actively 'silent' regarding her own sexuality and (other) lesbian players. Elling et al. showed how many Dutch heterosexual and lesbian elite women football players and their audience, share such a strategic, public promotion of a more 'feminine' image of women's football and a silencing of visible lesbian sexuality. ${ }^{45}$ Such strategic position, however, makes them complicit to the reproduction of dominant sports media discourses privileging heterosexuality and emphasized femininity. ${ }^{46}$ Emma as a self - defined heterosexual woman - if I see a pretty male footballer on TV, I also nudge my girlfriends' - is more reflective on this issue and acknowledges how she and her colleagues negotiate on when and why reference to lesbian sexuality of - 'a lot of the' - players is appropriate or irrelevant. She does not reject sexual self-marketing by players or sexualization of players by fans as such, but does clearly disapprove of a (hetero)sexist presence as main reason or prerequisite for media-attention. As highlighted by Thorpe et al with respect to the self-promotion of sportswomen $^{47}$, both Lisa and Emma are clearly negotiating tensions within new feminist approaches regarding the celebration of specific emphasized femininities as a 'locus of empowerment' vis-a-vis a 'site of control' under constant regulation.

Our findings showed that such regulation by neoliberal powers in contemporary society is broader than a focus on bodily representation of football players and female experts on the game alone. Women's football experts are expected to further incorporate dominant discourses and economic principles to garner greater visibility and economic opportunity as Emma and Lisa experienced and negotiated prior to and during WEURO 2017. ${ }^{48}$ Emma's 'different' approach in her reporting of Dutch women's football since 2012 was often met with criticism by her male colleagues from the sports media department she worked for. Her more positive approach of the game, more personal or human-interest interview style and critical reflection on institutional developments surrounding women's football, was often not regarded as newsworthy enough or disqualified as a kind of 'promotional journalism', as found by Knoppers and Elling. ${ }^{49}$

Still, both Emma's and Lisa's expert voices on women's elite football were partly recognized during WEURO 2017. However, Emma's narrative also recalls how her expertise has been (mis) used as well by other (mainstream media) journalists and that during post WEURO such outsider mainstream voices have to some degree even silenced hers. Both stories show how relative outsider expert voices during a celebratory event like WEURO 2017 are expected not be too critical of mainstream media and/or male journalists, club managers and sponsors, or of dominant 'women-versus-men' narratives that have long hindered the development of women's football. ${ }^{50}$ This shows how the popularity of and increased attention for women's football in media can go hand in hand with a hegemonic gender discourse that constructs men's football as normative. Both Emma and Lisa to some extent profited from extra media appearance and economic opportunities in the run-up to and during WEURO 2017. However, their unique and longstanding knowledge and expertise in the field didn't always match hegemonic (sports) media marketing and consumerism logics during WEURO 2017. Lisa explained that for her it was easy to tell the privileged 'positive story' of the development of women's football, because the results of the national team reinforced such a positive vibe. However, she is also mindful of her economic dependent position within the field of women's elite football, enforcing her to strategically negotiate when and how to express her more critical voice. Fitting to her more neoliberal feminist perspective regarding gender and sexuality, Lisa again tends to frame her position in terms of personal choice and identity. For Emma the necessity of self-marketing within the sports media market as a young journalist seems much more of a struggle. Even though she found her 
promising 'niche' of women's football years ago, ${ }^{51}$ it hasn't paid off into more financial security, and WEURO 2017 may even have enforced economic uncertainly, since many 'mainstream' colleagues now seem less reluctant to cover women's football. The little financial security of both relatively successful young women in the women's football media field also matched the slow developments in the professionalization of elite women's football in the Netherlands as a whole. ${ }^{52}$ Despite the European title of the national team and successive personal transfers of internationals to foreign leagues, more financial stability remains one of the largest challenges for the Dutch premier league. Both Emma's and Lisa's narratives exemplify how market mechanisms may stimulate creativity and innovation - like Emma's crowd-funding and book initiative and Lisa's foundation of her own brand -, but simultaneously be accompanied by limitations and restricted freedom. Their accounts illustrate Couldry's argument how neoliberalism has not only promoted personal freedom and voice to a certain extent, but has even more strongly worked as a voicedenying rationality. ${ }^{53}$ Therefore, regardless our optimism about future media coverage of women's football and gender equity in football journalism, we have to remain critical of linear and transformative developments, especially regarding ascribed transformative powers of (winning) international sport events like the WEURO 2017.

\section{Notes}

1. Het Parool is a Dutch national newspaper based in the capital Amsterdam that also has a special focus on the city itself.

2. Prange and Oosterbaan, Vrouwenvoetbal in Nederland.

3. 'Het EK is het Gesprek van de Dag'.

4. E.g. Black and Fielding-Lloyd, 'Re-establishing the "outiders"'; Fink, 'Female athletes, Women's Sport'; Musto et al., 'From Frizzle to Sizzle'; and Delorme and Pressland, 'The Visibility of Female Athletes'.

5. Peeters and Elling, 'The Coming of Age of Women's Football'.

6. Antunovic and Whiteside, 'Feminist Sport Media Studies'; Knoppers and Elling, "'We Do Not Engage in Promotional Journalism"'; Elling et al, 'Tussen Nieuwe Heldinnen'; and Van Sterkenburg, 'Migration, Ethnicity and Sport Media Content'.

7. Pfister, 'Assessing the Sociology of Sport'.

8. Bruce, 'Reflections on Communication and Sport', 133.

9. Knoppers and Anthonissen, 'Women's Soccer in the United States and The Netherlands'; Pfister, 'Assessing the Sociology of Sport'.

10. Couldry, Why Voice Matters, 117.

11. Riessman, Narative Methods for the Human Sciences.

12. Couldry, Why Voice Matters.

13. Ibid., 7 .

14. Ibid., 7-8.

15. Ibid.

16. Riessman, Narative Methods for the Human Sciences.

17. Couldry, Why Voice Matters, 2.

18. Mirowski, Postface'.

19. Ibid., 437.

20. Gill and Scharf, New Femininities; and Harris and Dobson, 'Theorizing Agency in Post-Girlpower Times'.

21. Cole and Hribar, 'Celebrity Feminism'.

22. Christopherson et al., 'Two Kicks Forwards, One Kick Back'.

23. Thorpe et al., 'Sportswomen and Social Media'.

24. Buitelaar, 'I Am the Ultimate Challenge'; Frank, 'Letting Stories Breathe'.

25. Sykes, 'Turning the Closets Inside/Out'.

26. Fawcett and Hearn, 'Researching Others'.

27. Berger, 'Now I See It, Now I Don't'.

28. Riessman, 'Narrative Analysis'.

29. Smith and McGannon, 'Developing Rigor in Qualitative Research'.

30. Derks, 'Hard Gras'.

31. Scraton et al., 'It's Still a Man's Game'.

32. Christopherson et al., 'Two Kicks Forwards, One Kick Back'; Elling et al., Tussen Nieuwe Heldinnen, Voetbalbabes en Lerende Amateurs'. 
33. A 'professional career' in women's football in the Netherlands only means that players get some financial compensation, which in itself is not enough for an ordinary living. Only some top players of the clubs earn extra through for example personal sponsors.

34. The version that focuses on men's football is the original incarnation of the YouTube programme. Lisa and her team were able to borrow the studio and equipment to produce the women's edition.

35. Hermans et al, Nederlandse Journalisten in 2010.

36. Couldry, Why Voice Matters.

37. Riessman, Narrative Methods for the Human Sciences.

38. Peeters and Elling, 'The Coming of Age of Women's Football'.

39. Christopherson et al., 'Two Kicks Forwards, One Kick Back'; and Godoy-Presland and Griggs, 'The Photographic Representation of Female Athletes'.

40. Bruce, 'Reflections on Communication and Sport'; Kolnes, 'Heterosexuality as an Organizing Principle'; and Elling et al., 'Tussen Nieuwe Heldinnen, Voetbalbabes en Lerende Amateurs'.

41. Gill and Scharf, New Femininities; and Thorpe et al., 'Sportswomen and Social Media'.

42. Elling et al., 'Tussen Nieuwe Heldinnen, Voetbalbabes en Lerende Amateurs'; and Kolnes, 'Heterosexuality as an Organizing Principle'.

43. Hover et al., Creating Social Impact with Sport Events.

44. Caudwell, 'Women's Football in the United Kingdom'; Kolnes, 'Heterosexuality as an Organizing Principle'; and Elling et al., 'Tussen Nieuwe Heldinnen, Voetbalbabes en Lerende Amateurs'.

45. Elling et al., 'Tussen Nieuwe Heldinnen, Voetbalbabes en Lerende Amateurs'.

46. Bruce, 'Assessing the Sociology of Sport'.

47. Thorpe et al., 'Sportswomen and Social Media'.

48. Antunovic and Whiteside, 'Feminist Sport Media Studies'; and Hermans et al, Nederlandse Journalisten in 2010.

49. Knoppers and Elling, 'We Do Not Engage in Promotional Journalism'.

50. Peeters and Elling, 'The Coming of Age of Women's Football'; and Prange and Oosterbaan, Vrouwenvoetbal in Nederland.

51. Peeters and Elling, 'The Coming of Age of Women's Football'.

52. Prange and Oosterbaan, Vrouwenvoetbal in Nederland.

53. Couldry, Why Voice Matters.

\section{Disclosure statement}

No potential conflict of interest was reported by the authors.

\section{Bibliography}

Antunovic, D.A., and E. Whiteside. 'Feminist Sport Media Studies: State of the Field.' in Feminist Approaches to Media Theory and Research, ed. D. Harp, J. Loke, and I. Bachmann, 111-130. London: Palgrave MacMillan, 2018.

Berger, R. 'Now I See It, Now I Don't: Researcher's Position and Reflexivity in Qualitative Research.' Qualitative Research 15 (2015): 219-234.

Black, J., and B. Fielding-Lloyd. 'Re-establishing the “outsiders”: English Press Coverage of the 2015 FIFA Women's World Cup.' International Review for the Sociology of Sport 53 (2017): 1-20.

Bruce, T. 'Reflections on Communication and Sport: On Women and Femininities.' Communication \& Sport 1 (2013): 125-137.

Bruce, T. 'Assessing the Sociology of Sport: On Media and Representations of Sportswomen.' International Review for the Sociology of Sport 50 (2015): 380-384.

Buitelaar, R. "I Am the Ultimate Challenge". Accounts of Intersectionality in the Life-story of a Well-Known Daughter of Moroccan Migrant Workers in the Netherlands.' European Journal of Women's Studies 13 (2006): 259-276.

Caudwell, J. 'Women's Football in the United Kingdom: Theorizing Gender and Unpacking the Butch Lesbian Image.' Journal of Sport and Social Issues 23 (1999): 390-402.

Christopherson, N., M. Janning, and E.D. McConnell. 'Two Kicks Forward, One Kick Back: A Content Analysis of Media Discourses on the 1999 Women's World Cup Soccer Championship.' Sociology of Sport Journal 19 (2002): 170-188.

Cole, C., and A. Hribar. 'Celebrity Feminism: Nike Style Post-Fordism, Transcendence, and Consumer Power.' Sociology of Sport Journal 12 (1995): 347-369.

Couldry, N. Why Voice Matters: Culture and Politics after Neoliberalism. Sage: London, 2010. 
Delorme, N., and A. Pressland. 'The Visibility of Female Athletes: A Comparison of the Sochi 2014winter Olympic Games Coverage in French, British and Spanish Newspapers.' Sociology of Sport Journal 33 (2016): 317-333.

Derks, M. 'Hard Gras. Sekse, Identiteit En Voetbalgeschiedenis.' Tijdschrift Voor Genderstudies 2 (1999): 5-15.

Elling, A., R. Peeters, and L. Stentler. 'Tussen Nieuwe Heldinnen, Voetbalbabes En Lerende Amateurs.' in Vrouwenvoetbal in Nederland. Spiegel En Katalysator Van Maatschappelijke Verandering, ed. M. Prange and M. Oosterbaan, 209-236. Utrecht/Amsterdam: Uitgeverij Klement/Atria, kennisinstituut voor emancipatie en vrouwengeschiedenis, 2017.

Fawcett, B., and J. Hearn. 'Researching Others: Epistemology, Experience, Standpoints and Participation.' International Journal of Social Research Methodology 7 (2004): 201-218.

Fink, J.S. 'Female Athletes, Women's Sport, and the Sport Media Commercial Complex: Have WeReally "Come a Long Way, Baby"?' Sport Management Review 18 (2015): 331-342.

Frank, A.W. Letting Stories Breathe: A Socio-Narratology. University Press: Chicago, 2010.

Gill, R., and C. Scharff. New Femininities: Postfeminism, Identity and Neoliberalism. Palgrave: Basingstoke, 2011.

Godoy-Presland, A., and G. Griggs. 'The Photographic Representation of Female Athletes in the British Print Media during the London 2012 Olympic Games.' Sport in Society 17 (2014): 808-823.

Harris, A., and A.S. Dobson. 'Theorizing Agency in Post-Girlpower Times.' Continuum 29 (2015): 145-156.

Hermans, L., M. Vergeer, and A. Pleijter. Nederlandse Journalisten in 2010: Onderzoek Naar deKenmerken Van De Beroepsgroep, Professionele Opvattingen En Het Gebruik Van Digitale Media in Het Journalistieke Werk. Nijmegen: Radboud Universiteit, 2012.

'Het EK Is Het Gesprek Van De Dag: Recordaantal Kijkers En Oranje Voorpagina's'. NOS, August 7, 2017. http:// www.nos.nl

Hover, P., B. Dijk, K. Breedveld, F.J.A. Eekeren, and S.H. van. Creating Social Impact with Sport Events. Mulier Instituut/Utrecht University: Utrecht, 2016.

Knoppers, A., and A. Anthonissen. 'Women's Soccer in the United States and the Netherlands. Differences and Similirities in Regimes of Inequality.' Sociology of Sport Journal 20 (2003): 351-370.

Knoppers, A., and A. Elling. "WWe Do Not Engage in Promotional Journalism”: Discursive Strategies Used by Sport Journalists to Describe the Selection Process.' International Review for the Sociology of Sport 39 (2004): 57-73.

Kolnes, L.J. 'Heterosexuality as an Organizing Principle in Women's Sport.' International Review for the Sociology of Sport 30 (1995): 61-75.

Mirowski, P. 'Postface: Defining Neoliberalism.' in The Road from Mont Pelerine. The Making of theNeoliberal Thought Collective, ed. P. Mirowski and D. Plehwe, 417-457. Cambridge, US and London, England: Harvard University Press, 2009.

Musto, M., C. Cooky, and M.A. Messner. “from Fizzle to Sizzle!” Televised Sports News and theProduction of Gender-Bland Sexism.' Gender \& Society 31 (2015): 573-596.

Peeters, R., and A. Elling. 'The Coming of Age of Women's Football in the Dutch Sports Media, 1995-2013.' Soccer and Society 16 (2015): 620-638.

Pfister, G. 'Assessing the Sociology of Sport: On Women and Football.' International Review for the Sociology of Sport 50 (2015): 563-569.

Prange, M., and M. Oosterbaan, eds. Vrouwenvoetbal in Nederland. Spiegel En Katalysator Vanmaatschappelijke Verandering. Uitgeverij Klement/Atria: Utrecht/Amsterdam, 2017.

Riessman, C.K. 'Narrative Analysis.' Narrative, Memory \& Everyday Life. In N. Kelly, C. Horrocks, K. Milnes, B. Roberts and D. Robinson (Eds.), (pp. 1-7). Huddersfield, England: University of Huddersfield, 2005.

Riessman, C.K. Narrative Methods for the Human Sciences. Sage: London, 2008.

Scraton, S., K. Fasting, G. Pfister, and A. Brunell. 'It's Still a Man's Game: The Experiences of Top-Level European Women Footballers.' International Review for the Sociology of Sport 34 (1999): 99-111.

Smith, B., and K.R. McGannon. 'Developing Rigor in Qualitative Research: Problems and Opportunities within Sport and Exercise Psychology.' International Review of Sport and Exercise Psychology 11 (2018): 101-121.

Sykes, H. 'Turning the Closets Inside/Out: Towards a Queer-Feminist Theory in Women's Physical Education.' Sociology of Sport Journal 15 (1998): 154-173.

Thorpe, H., K. Toffoletti, and T. Bruce. 'Sportswomen and Social Media: Bringing Third-Wave Feminism, Postfeminism, and Neoliberal Feminism into Conversation.' Journal of Sport and Social Issues 41 (2017): $359-383$.

Van Sterkenburg, J. 'Migration, Race/ethnicity and Sport Media Content: An International Overview and Suggestions for a Future Research Agenda.' in Sage Handbook of Media \& Migration, ed. K. De Smet, K. Leurs, M. Georgiou, S. Witteborn, and R. Gajjala, London: Sage, forthcoming. 